\title{
КОСМИЧЕСКИЙ МОНИТОРИНГ КАК СРЕДСТВО ПОВЫШЕНИЯ ЭФФЕКТИВНОСТИ ГЕОЛОГОРАЗВЕДКИ
}

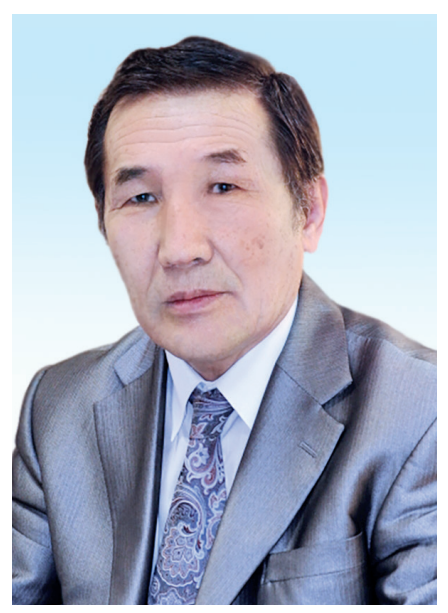

М. МОЛДАБЕКОВ,

академик Национальной академии наук

и Национальной инженерной академии Республики Казахстан

своем Послании народу Казахстана от 1 сентября 2020 г. Глава государства К.К. Токаев сказал: «Длительный нефтяной суперцикл, похоже, завериился. Следует быть готовым к совершенно новой конъюнктуре мирового рынка. Создание по-настоящему диверсифицированной, технологичной экономики для нас не просто необходмость, этот путь уже безальтернативен». Поэтому, как отметил далее Глава государства, новый экономический курс нашей страны должен базироваться на семи основных принципах, среди которых он назвал принцип роста производительности, повышение сложности и технологичности экономики, и при этом мы должны исходить из наших конкурентных преимуществ и реальных возможностей.

«Как сделать Казахстан самой конкурентоспособной и передовой нефтяной страной в мире», - так называется статья первого вице-президента Национальной инженерной академии РК, академика АН КазССР, Почетного нефтяника СССР Н.К. Надирова [1], в которой он пишет, что ключом к прорыву в нефтяной отрасли Казахстана, которая является локомотивом экономики нашей страны, может и должно стать внедрение в отрасль инновационных механизмов.

Как отмечается в статье, в условиях резко обострившейся мировой конъюнктуры среди нефтедобывающих стран уже недостаточно просто добыть и поставить нефть отечественным и зарубежным потребителям, надо добыть ее более эффективно, перерабатывать и использовать более экономично, чем это делают конкуренты. 
Сравнение средней цены безубыточности нефти 46 долларов за баррель у Казахстана и 17 долларов за баррель у Саудовской Аравии предельно ясно иллюстрирует необходимость прорыва в конкурентоспособности производства нашей нефти по всему циклу, включающему поиск и разведку месторождений, добычу, подготовку, транспортировку и переработку нефти, вплоть до поставок нефтепродуктов конечному потребителю.

Исходя из этого, автор делает важный вывод о том, что только широкое внедрение инновационных основ и активное внедрение самых передовых отечественных и зарубежных разработок по всему циклу отрасли обеспечат конкурентоспособное будущее страны. Далее автор статьи приводит краткий обзор созданных учеными, инженерами, изобретателями Национальной инженерной академии РК технологий, внедрение которых позволит резко снизить себестоимость и повысить эффективность производства нефти. Эти технологии, по оценке разработчиков и специалистов, позволяют говорить о возможности снижения себестоимости даже трудноизвлекаемой нефти до 4-6 долларов за баррель и даже ниже, выведя ее в разряд самых эффективных в мире.

Такая перспектива развития нефтегазовой отрасли непременно будет выдвигать на первый план вопросы расширения геологоразведочных работ для приращения реальных запасов углеводородного сырья. Начальные этапы геологоразведочных работ включают геологические, геофизические, геохимические, аэрокосмические и другие исследования, которые сопряжены с научными исследованиями и тематическими работами. Такие работы предусматриваются проектом Государственной программы геологической разведки на 2021-2025 годы.

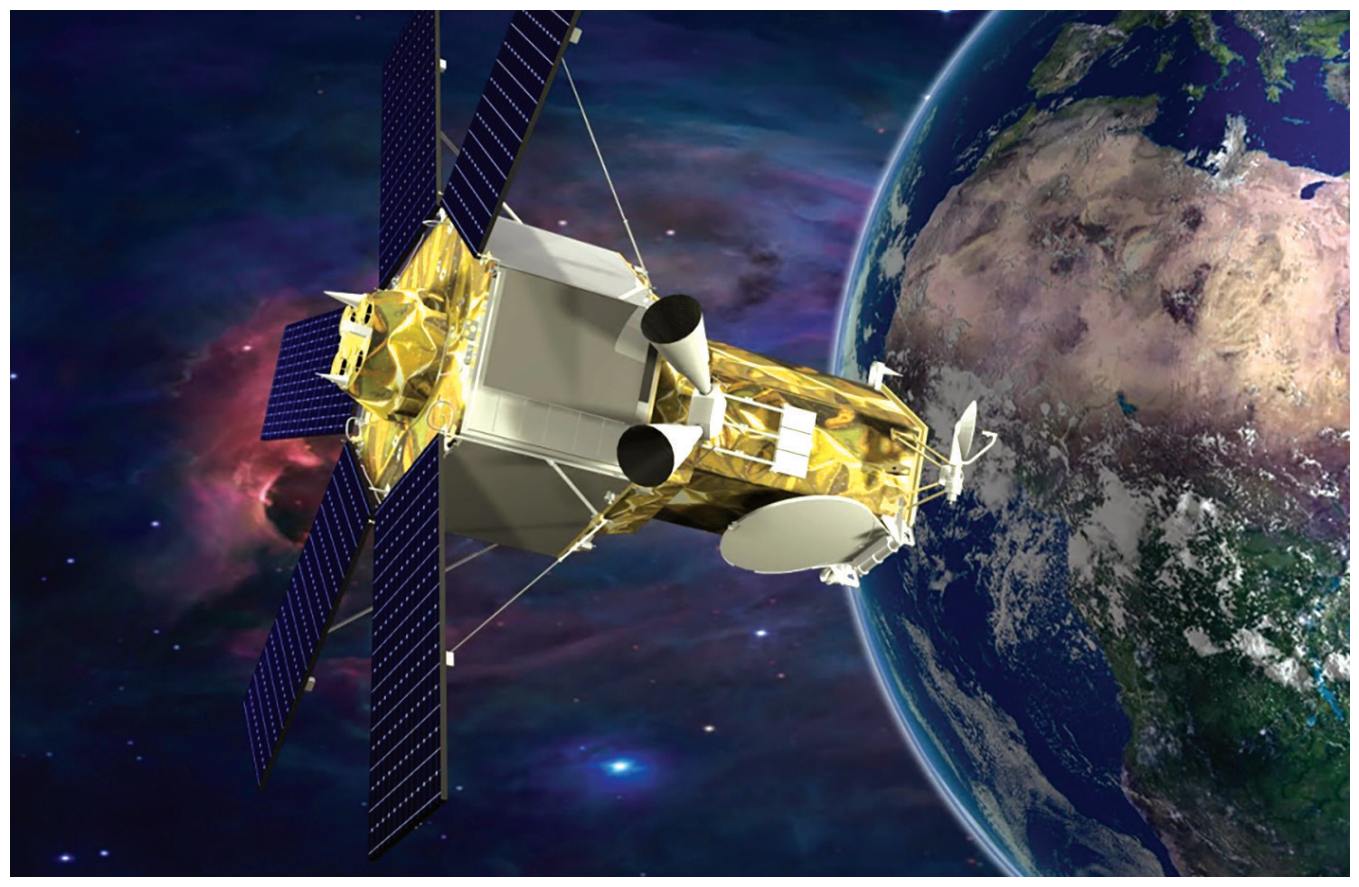


В статье отмечается, что традиционные геологические, геофизические, геохимические методы исследований являются трудоемкими, дорогостоящими и, самое главное, не всегда достаточно надежными, подтверждаемость полученных при этом результатов в среднем составляет $25 \%$. Поэтому в последние годы ученые стали уделять внимание новым подходам и современным средствам в решении задач геологоразведки. Действенным современным средством решения задач отраслей экономики таких, как недропользование является космический мониторинг. Проблематике выявления месторождений с применением космического мониторинга посвящены работы академика Н.К. Надирова и его коллег [2-5].

Технологии, основанные на космическом мониторинге, по данным их разработчиков, позволяют значительно удешевить поиск, снизить финансовые и временные затраты, при этом высока скорость получения более точной информации. При детальных исследованиях точность определения места поисковой скважины увеличивается с 25\% до 50-60\%, что дает огромную экономию средств на постановку буровых работ.

В качестве примера применения космического мониторинга в статье приводится всемирно признанная технология «Метод видеотепловизионной генерализации Мухамедярова», разработанная учеными Татарстана [6-9]. Технология позволяет прозондировать отснятые со спутника интересующие территории послойно, как в компьютерной томографии, с определенным шагом по вертикали от 1 до 120 метров, выявить в глубинах до 12 км перспективные геологические структуры на нефть, газ и другие полезные ископаемые. Приведены примеры использования технологии на конкретных территориях нефтяных месторождений Казахстана и Татарстана.

С учетом мирового опыта в Казахстане создана необходимая законодательная база для применения космического мониторинга. Основные положения о космическом мониторинге были определены в Законе Республики Казахстан от 8 апреля 2016 года № 490-V ЗРК «О внесении изменений и дополнений в некоторые законодательные акты Республики Казахстан по вопросам космической деятельности». Данный Закон внес изменения в Земельный кодекс, Водный кодекс, Лесной кодекс, Экологический кодекс и в ряд законов. Основной целью этих изменений было повышение роли использования данных дистанционного зондирования Земли (ДЗЗ) из космоса для решения задач недропользования, своевременного выявления происходящих в различных отраслях экономики изменений, их оценки, прогноза дальнейшего развития и выработки рекомендаций по предупреждению и устранению последствий негативных процессов.

Уполномоченным органом по космическому мониторингу является Аэрокосмический комитет (Казкосмос). Для обеспечения финансирования космического мониторинга Правительством РК была принята Подпрограмма 102 «Услуги по предоставлению космических снимков государственным органам и организациям, получаемые от космической системы дистанционного зондирования Земли Республики Казахстан» в рамках Республиканской бюджетной программы 010 «Обеспечение сохранности и расширения использования космической инфраструктуры». Основ- 
ным исполнителем этой подпрограммы определено АО «Национальная компания «Казахстан Гарыш Сапары» (КГС), которое является Национальным оператором Космической системы дистанционного зондирования Земли Республики Казахстан.

Об экономическом эффекте подпрограммы можно судить по конкретной информации от Генеральной прокуратуры РК. Используя возможности разработанного КГС геопортала, Генеральной прокуратурой РК за период 2018-2019 годы выявлено более 37 тысяч участков, площадью 9,6 млн га неиспользуемых земель сельскохозяйственного назначения с кадастровой стоимостью порядка 700 млрд тенге, из них возвращено в оборот или государству около 11 тысяч земельных участков площадью 4 млн га с кадастровой стоимостью 149 млрд тенге. На территории 21 города выявлены 972 тысячи незарегистрированных земельных участков.

Таким образом, космический мониторинг в силу яркой наглядности и обзорности является не только средством повышения эффективности геологоразведки, он необходим и при решении проблем, связанных с сильным загрязнением поверхности Земли, выбросами отравляющих веществ и отходами промышленных предприятий, в том числе и от нефтегазового комплекса, а также для решения множества других вопросов жизнедеятельности человека.

\section{ЛИТЕРАТУРА}

[1] Надиров Н.К. Как сделать Казахстан самой конкурентоспособной и передовой нефртяной страной в мире // Нефть и газ. - 2020. - № 3-4. (117-118). - С. 7-51.

[2] Надиров Н.К. Влияет ли космос на нефтегазовые дела? // Нефть и газ. - 2005. № 3. - С. 123-128.

[3] Надиров Н.К. Влияние космоса на добычу и транспортировку нефти. // Нефть и газ. 2010. - № 5. - С. 91-104.

[4] Надиров Н.К. Космические технологии выявления нефтегазовых месторождений // Доклады 9 Международных научных Надировских чтений. - Алматы, 2011. - С. 9-25.

[5] Зейлик Б.С., Сыдыков К.Ж. Взгляд из космоса ведет к месторождениям нефти и газа. // Нефтьь и газ Казахстана. - 1999. - № 6. - С. 38-46.

[6] Мухамедяров Р.Д. К использованию метода видеотепловизионной генерализации при поисках месторождений природного битума // Нефрть и газ. - 2011. - № 4. - С. 51-59.

[7] Мухамедяров Р.Д. Метод видеотепловизионной генерализации и его использование в геолого-геофизических исследованиях природных ресурсов Земли. // Тезисы докладов на международном семинаре «Дни космоса в Казахстане - 2014», Астана. 2014.

[8] Мухамедяров Р.Д. Изучение генезиса битумных месторождений песчаникового типа методом видеотепловизионной генерализации. // Нефть и газ. - 2014. - № 6. С. 105-116.

[9] Мухамедяров Р.Д., Дабаев А.И., Антипов С.М. Технология «МВТГМ» для выявления нефти на больших глубинах мест бурения скважин // Нефть и газ. - 2017. - № 1. C. 25-30. 